Rhode Island School of Design

DigitalCommons@RISD

Faculty \& Librarian Work

RISD Faculty \& Librarians

$5-2013$

\title{
Veronese's Goblets: Glass Design and the Civilizing Process
}

Pascale Rihouet

Rhode Island School of Design, prihouet@risd.edu

Theory \& History of Art \& Design Department

Rhode Island School of Design, thad@risd.edu

Follow this and additional works at: https://digitalcommons.risd.edu/faculty_work

Part of the Ancient, Medieval, Renaissance and Baroque Art and Architecture Commons, and the Art and Design Commons

\section{Recommended Citation}

Rihouet, Pascale and Department, Theory \& History of Art \& Design, "Veronese's Goblets: Glass Design and the Civilizing Process" (2013). Faculty \& Librarian Work. 1.

https://digitalcommons.risd.edu/faculty_work/1

This Book is brought to you for free and open access by the RISD Faculty \& Librarians at DigitalCommons@RISD. It has been accepted for inclusion in Faculty \& Librarian Work by an authorized administrator of DigitalCommons@RISD. For more information, please contact mpompeli@risd.edu. 
doi:10.1093/jdh/eps056

Journal of Design History
Veronese's Goblets: Glass Design and the Civilizing Process

\section{Pascale Rihouet}

Taking its cue from Veronese's lavish Wedding at Cana (1563), this article explores the meanings of fine and ordinary glassware, focusing on the performative value of Renaissance goblets. Drinking vessels are analysed here as tools for the gradual transformation of human behaviour, or the 'Civilizing Process' that sociologist Norbert Elias expounded. In the mid-sixteenth century, new designs for fine glasses supported and shaped the proper conduct expected of guests and servants in banquets. Iconographic sources such as the exquisite wine cups depicted by Veronese, didactic literature and the objects themselves document the kind of challenges and expectations that handling glass in public induced. By the end of the sixteenth century, the affordability of simple but elegant goblets allowed common people to adopt the drinking manners of the elite, thus furthering the association between glassware and the concept of civility.

Keywords: design history—glass_-material culture—Renaissance—ritual—-table manners

In the foreground of Veronese's celebrated Wedding at Cana of 1563 [1], a superbly dressed cupbearer gracefully holds his baluster-stemmed cup aloft as he acknowledges Christ's miraculous production of wine [2]. This suggests that the elite took advantage of complex shapes for glasses to exhibit a seemingly effortless deportment in society, the sprezzatura so dear to Baldassare Castiglione's Courtier (1528). ${ }^{1}$ From the mid-sixteenth century, novel designs for fine glasses supported and shaped the proper conduct expected of guests and servants in a banquet. Combining material culture, iconography and cultural history, this essay considers fine glassware as an essential tool in the 'Civilizing Process' expounded by Norbert Elias.' Handling a sophisticated goblet in public posed a series of challenges that made the self-discipline demanded of the nobility conspicuous. Looking at the 'social life' of particular drinking vessels complements Elias' insights on the passage from courtesy to civility in the sixteenth century. ${ }^{3}$ Beside the conduct manuals cited by Elias, Renaissance Italian literature, depictions of meals and the glasses themselves build a fruitful avenue to explore the 'Changes in the Behaviour of the Secular Upper Classes'. ${ }^{4}$ Highlighting the performance value of refined goblets, this article contributes to an anthropological approach to the history of design. ${ }^{5}$

\section{A Venetian banquet}

Veronese's Wedding at Cana has been praised from its inception (1562-1563) up to this day for its vivid colour palette, its Palladian architectural setting and for its depiction of an unprecedented number of feasting figures. ${ }^{6}$ While remaining faithful to the Gospels' account and traditional iconographic elements, Cana renders the splendour of a contemporary lavish banquet. ${ }^{7}$ Renaissance feasts show a new complexity in terms of more elaborate food and its presentation, vast quantities of silver (see Veronese's huge credenza in the upper left, here both for display and practical use), intricate scenery and various entertainments. ${ }^{8}$
(C) The Author [2012]. Published by Oxford University Press on behalf of The Design History Society. All rights reserved. 


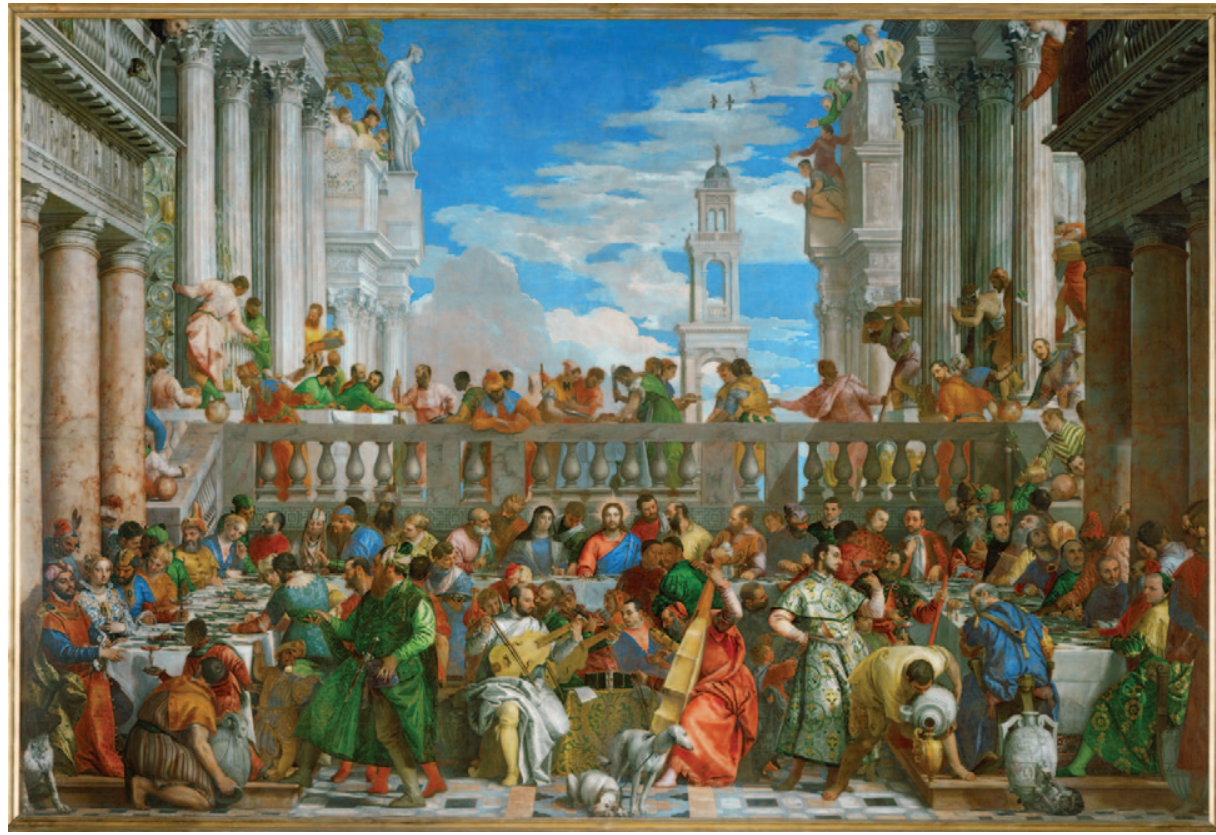

Facing the groom in the left foreground, Veronese's stout steward (scalco) perfectly fits Giambattista Rossetti's description in his contemporary treatise: 'of over average height because it makes him look much more grave and also will allow him to dominate the tables [as he surveys everything]'. ${ }^{9}$ As supreme orchestrator of the meals, he had to stand close to the lord and be 'seen by all, without moving places, with gestures only, [so that he] will command and be understood by all'. The eloquent and

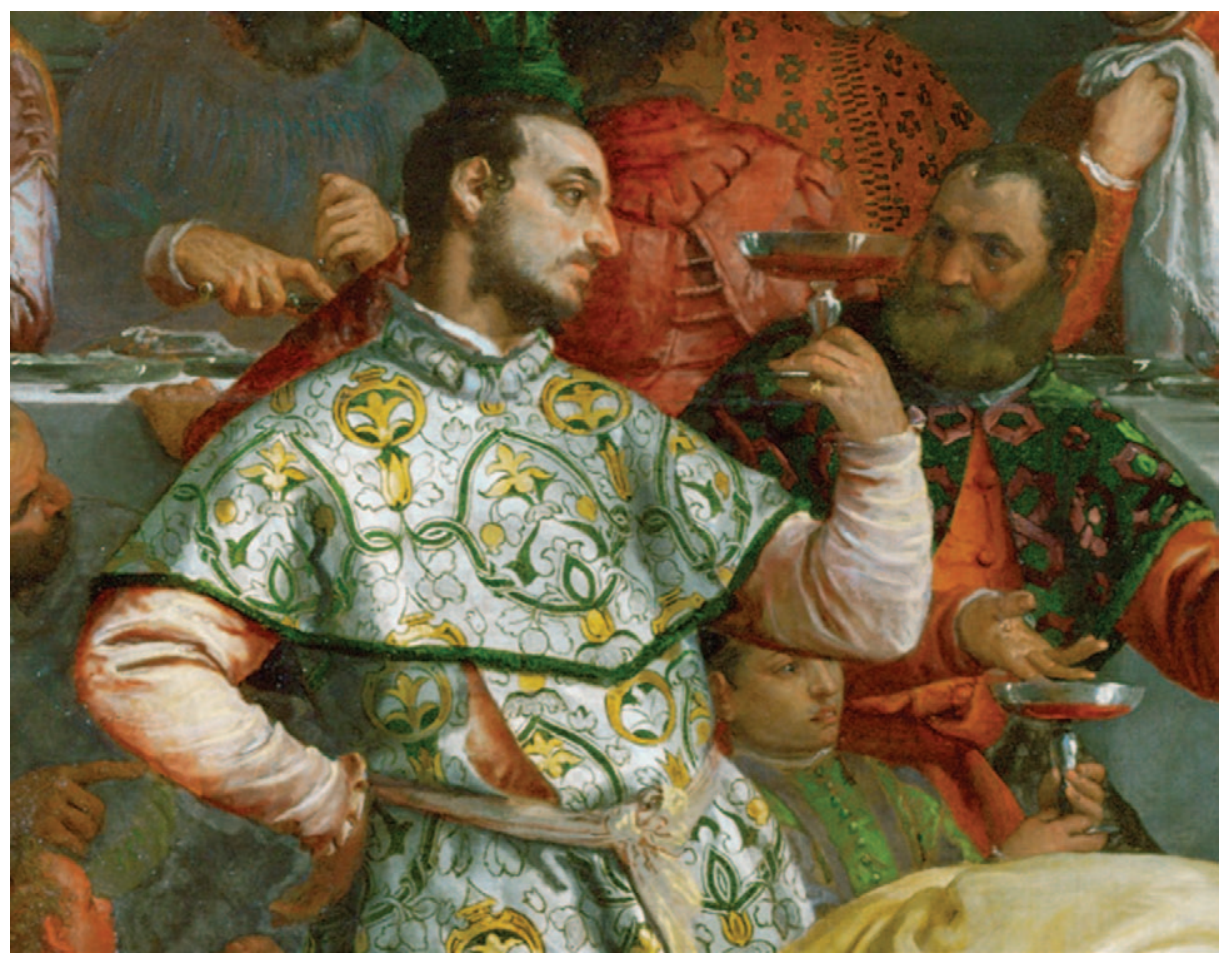

Figg 1. Paolo Veronese (1522-1588), The Wedding at Cana (post-restoration), $1562-1563,677 \times 994 \mathrm{~cm}$, from the Benedictine Convent of San Giorgio Maggiore, Venice. Louvre, Paris, France. Photo: Erich Lessing/Art Resource, NY
Figy 2. Paolo Veronese, The Wedding at Cana, 1562-1563, detail of [1]: the cupbearer. Photo: Erich Lessing/Art Resource, NY 
well-mannered scalco must, in another prescriptive source, 'above all, make himself feared - "cum omne possibile piacevoleza" [in all possible amenity]'. ${ }^{10}$ Logically, he would have observed the unfolding of such a miracle closely and reported it to his master. ${ }^{11}$

Another key professional, the cupbearer, exudes the grace and elegance of Baldassare Castiglione's Cortegiano, following cook and scalco Domenico Romoli's observations. ${ }^{12}$ With white and delicate hands and dressed in long and rich fabrics, the 'coppiere' must be of 'honourable bodily stature and extremely clean in his life and his clothing'. This affable, well-born gentleman oversaw the distribution of drinks and performed the eminent duty of checking the wine for possible poisoning ('fare la credenza'). ${ }^{13}$ He was also a connoisseur who could, by 'reading' a glass, assess which wine would suit best his master's health-an attitude that his gesture endorses in Veronese's painting. ${ }^{14}$

Reminding us not to take depictions at face value because of the artist's license dear to him, Veronese departed from reality with illogical spatial arrangements, fanciful sartorial accoutrements, the absence of sugar sculptures and the suggested sequence of courses. ${ }^{15}$ However, he superbly illustrated the refined dining etiquette prevailing in Renaissance Italy and characterized by the 'individualization' of tableware with individual trenchers, knives and, as only in Italy, forks. ${ }^{16}$ In addition, guests also have their own glass. In the late Middle Ages and in the Renaissance, vessels were shared by two or more guests. ${ }^{17}$ Italians, however, drank, by the sixteenth century, from individual vessels, unless the host had thought otherwise. ${ }^{18}$

\section{Civilizing table manners}

Individual table tools foster fine table manners which include keeping fingers, hands and mouth clean as well as adopting poised gestures, as conduct books recommend. In turn, table manners reveal a person's civility. ${ }^{19}$ As Elias pointed out, their codification must be credited to Medieval monastic writings from the twelfth century, notably by Hugh of Saint Victor. ${ }^{20}$ Since measure and moderation in one's gestures reveal the interior quality of the mind, manners in the refectory mattered as well.21 Paralleling this advice, poems circulated in courtly-aristocratic circles as mementos for the correct attitude at table, and didactic writings inculcated courtesy to children. ${ }^{22}$ For example, Bonvesin de la Riva, a tertiary Franciscan from Milan devised 'Fifty Courtesies at Table' (1288). ${ }^{23}$ Bonvesin's verses were reiterated three centuries later by popular writer Giulio Cesare Croce in his Cinquante cortesie overo creanze da tavola (1608). ${ }^{24}$ Thus, Medieval precepts formed the basis of Renaissance conduct books and were still valid into the early seventeenth century.

In their critique of Elias' theory, Sergio Bertelli and Giulia Calvi argued that Italian courts functioned in closed, internal circuit, and therefore treatises on court professions or on manners addressed only the elite. ${ }^{25}$ The wide readership suggested by the vast number of editions of several conduct books invalidates such a restrictive interpretation of the 'Civilizing Process'. Erasmus' On Civility in Boys (1530) went through eighty editions in the 1500s, and Giovanni della Casa's Galateo (first published in Italian in 1558) reached the educated people of Europe through its Latin versions, its numerous translations, or its paraphrases. ${ }^{26}$ French and Italian treatises did address courtly-aristocratic circles; Della Casa's original text promoted social distinction by pitting the manners of the nobility against those of women or lowly servants. But Elias has shown that its translations tended to erase social differentiation. ${ }^{27}$ Similarly, 
Erasmus' best seller presented his precepts as general human rules rather than rules oriented towards the elite. ${ }^{28}$ The diffusion of texts on refined conduct in the sixteenth century thus responds to a social need and points to the start of a gradual transformation in behaviour in a society that will eventually define itself as possessing the quality and status of a 'civilization'.

As Elias argues, Renaissance conduct books (starting with Erasmus) offer a comprehensive outlook on bodily carriage, gestures, dress and facial expression, by including situations other than just mealtimes, as Medieval poems do. They also reveal a tendency to observe oneself and others' comportment while developing new standards of shame and repugnance in case of bad conduct. As Croce remarks '[do it this way] so that guests won't point at you' (ninth rule). While early terms for manners refer to courts (e.g. Hofzucht/courtesy/cortesia), Erasmus marks the turning point in the transition to 'civility', a world in which the 'invisible wall of affects' arose 'between one human body and another, repelling and separating [. . .] at the mere sight of many bodily functions of others'. ${ }^{29}$ The compulsion to check one another's behaviour along with a progressive refinement of outward manners took place from the sixteenth century.

'There is more [than physical abilities] to the entire virtue and perfection of a gentleman [. . . ]: at table before kings and princes, the manner of adjusting one's language towards people according to their rank and quality, their glances, their gestures and even the smallest signs or winks they might give. '30 This excerpt from the introduction to the French translation (1562) of Galateo, illustrates the mutual scrutiny that took place among courtiers. The self-discipline expected of noblemen at table was codified by etiquette and court ceremonial. ${ }^{31}$ Table etiquette or manners, as understood here, belong to the realm of ritual, in its generic sense of specifically timed, recurrent, actions that explicate and shape solemn events through symbols. This ensemble of controlled gestures conferred solemnity on the act of eating and drinking in company while showing consideration of others. A variety of sources tell us about the expert manipulation of glass vessels at table which sets a refinement of behaviour in motion, a 'civilizing process'.

\section{Ritualizing the act of drinking}

Table manners should not be studied only in their prescriptive form or as a form of hygiene in order to explain the advancement of the 'threshold of repugnance' from the seventeenth century. ${ }^{32}$ They should be analysed as a reflection of persistent rituals linked to hierarchy, purity and conviviality. ${ }^{33}$ These phenomena readily apply to the solemn drinking mores of the elite, with their highly codified serving and absorption of beverages.

Ritual precedence was already articulated by Bonvesin in 1288: if you sit next to an important person, you should abstain from food and beverage while he is drinking; or if your table neighbour happens to be a bishop, you should never lift your own glass before he does, 'out of education' (twenty-eighth and twenty-ninth rules). Croce's version (1608) is 'Remember that when your lord drinks, you may not drink' (thirtieth cortesia). ${ }^{34}$ Deference and hierarchy around drinks reigned in Renaissance European courts. ${ }^{35}$ In Italy, the Pope's act of drinking triggered a series of rituals which asserted his supremacy. For example, diners who were not seated at his table had to kneel; an ambassador hosted at the papal table would take off his hat and stand up. ${ }^{36}$ In 1628 , even the Grand Duke of Tuscany and his brother had to uncover their heads and to stand up when the pontiff drank. ${ }^{37}$ No one was supposed to drink before a prince, 
Fig 3. Annibale Carracci (Italian, c. 1560-1609), Boy Drinking, 1582-1583, Oil on canvas, $55.8 \times 43.7 \mathrm{~cm}$, The Cleveland Museum of Art, Leonard C. Hanna, Jr, Fund 1994.4. Photo: Cleveland Museum of Art. Reproduced with permission from The Cleveland Museum of Art

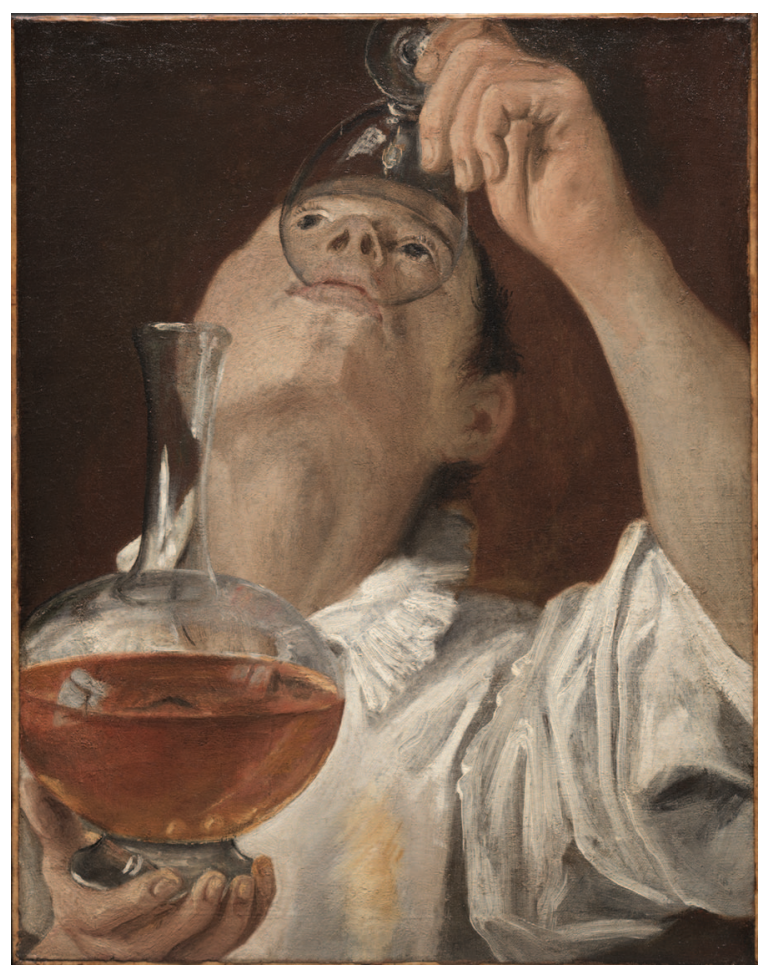
servants. ${ }^{46}$ and guests had to bare their heads ('far di beretta') until he was done. As he drank, his napkin would be changed, and the scalco covered the dish placed in front of him. ${ }^{38}$

Rituals of purity at table, already extant in antiquity, materialized during the Renaissance through the provision of immaculate linen. After each course, napkins were changed and an impeccably white tablecloth replaced the soiled one. ${ }^{39}$ Numerous Medieval and Renaissance manners books insist on wiping one's mouth and hands before drinking in order not to soil the edge of the cup. ${ }^{40}$

The calculated steps of servicing wine during a formal meal elevated this task to the status of a 'ceremony'. ${ }^{41}$ The 'skilful' servants were supposed to exude grace and 'diligently stand on their guard, adroit, when they wait tables'. ${ }^{42}$ Usually, each guest hailed a servant who, 'in an assured walk, [and] with a happy face' brought him wine in a personal cup..$^{43}$ At dinner time, servants used a torch to light up the wine cup on the way to the table, or a guest would stand up, seize a candle-holder, and keep it aloft while someone drank. ${ }^{44}$ Visibility of the beverage was important because of the risk of poisoning but, at the same time, it turned drinking into a conspicuous act.45 Once finished, the guest handed his cup back to the servant, who returned it to the credenza (sideboard) of wine, to be cleaned by the bottigliere. This practice, however, was different in Venice, as Veronese's Cana and other Venetian paintings show: glasses and wine jugs were kept on the table throughout the meal and refilled by the

Paintings help visualize the cupbearers' 'reverence' and 'dexterity'. For example, in Veronese's Supper in the House of Levi (1573), the servant on the far right tilts the glass bottle by holding it from its slim disk base. Annibale Carraci's Boy [a servant?] drinking of 1582 [3] and the central reveller of Titian's Bacchanal (1525) show an identical grasp of the carafe. This is also the way a waiter is supposed to present a filled-up cup. 'Never touch the upper rim of the cup with your thumb', says Bonvesin, but rather 'lift the cup from underneath and hold it with one hand only' (forty-third cortesia), while Croce's forty-first rule recommends to grasp your glass 'with dexterity so that the person to whom you are offering it may take it [easily].'

\section{Drinking and civility}

In Stefano Guazzo's 'Civil Conversation' (1574), the food is never referred to but wine is, implying that, in a formal meal, the act of drinking is conducive to demonstrating one's civility. In thirteen quatrains out of fifty, Bonvesin had already specified good drinking manners. Prescriptions such as wiping your lips, not drinking with food in your mouth, or emptying your glass before resting it on the table remind us that cups were shared. But in sixteenth-century Italy (as many paintings testify), it was common for guests to have their own glass. Giulio Croce's versified etiquette confirms that a single glass for two was unusual and applies the same rules: swallow your food before drinking, clean your mouth.

The need for self-control while handling one's vessel is well articulated in many conduct books: you should set an empty 
wine cup down 'fair and still' or 'gently'/'If a guest cannot take his glass without help, offer it to him but try to do it slowly' (the eleventh courtesy in both Bonvesin and (Croce). A fundamental rule is to not spill your beverage, which leads Bonvesin to advocate using both hands when drinking (twelfth cortesia). ${ }^{47}$ But this elegant manner was modified by the fifteenth century at the latest. ${ }^{48}$ In the Renaissance, you were supposed to 'seize your shallow bowl with three fingers as you drink', 49 a distinguished custom rejected by monastic communities that advocated the use of two hands 'in order to alienate ourselves from secular acts'. ${ }^{50}$ Renaissance visual sources further document that whatever their shape (shallow bowls, beakers, or goblets) or the material (metal, ceramics, or glass), vessels were supposed to be held at their base and by only a few fingers of one hand, usually the right one. ${ }^{51}$ In Botticelli's fourth episode of the Story of Nastagio degli Onesti (1483), or in Giorgio Vasari's Feast of Saint Gregory (1539) and Esther's Banquet (1548), guests in the foreground grasp their shallow wine cup with fingers cupped underneath it. ${ }^{52}$ While such banquet bowls were typically made of silver, the common shapes for glass vessels were simple beakers..$^{53}$ In formal settings, they, too, were held from their base with a few fingers, as many images show from the fourteenth into the eighteenth centuries [4, no. 2]. ${ }^{54}$ However, in the routine of everyday meals, the wealthy readily held their beakers by the palm, for a more convenient and secure grip. 55

Glass goblets present a trickier grasp because of their articulated shape. In Italian, 'calici' (chalices) designates all stemmed goblets whether the stem is squat or tall, interrupted by a knop (a spherical protuberance typical of chalice stems) or not, and regardless of the shapes of the bowl (funnel, hemispherical, inverted bell, shallow, etc.). In English, goblets refer to both footed and stemmed vessels. ${ }^{56}$ The 'footed cup' type consists of a bowl joining directly on a foot with or without a merese (a ring-shaped decorative joint, not blown) and knop (hollow and blown) [4 (nos 3-4), 5, 8, 9, 10]. Veronese's goblets belong to the stemmed type, which features a cup elevated on a full or hollow stem and resting on a flat disk or a flared foot $[2,6]$.
Fig 4. Gerard de Lairesse, 'Different handling of the same thing in persons of different conditions. Example 1: Taking hold of a glass', in Groot Schilderboek, 1707, plate 54. Photo: author/BnF. Reproduced with permission from Bibliothèque nationale de France

As iconographic evidence confirms, servants and guests alike preferably held their goblets by the base. This fundamental, elegant, gesture marked good manners throughout Europe. They could also be held from underneath, as does the black page serving the bridegroom in Cana [1]. ${ }^{57}$ When not held this way, goblets were typically carried and presented [5], filled up [6], or drunk firmly caught between thumb and index finger [3, 9]. Metal vessels were handled similarly, although they were heavier-and thus allowed a more stable hold-than glass. ${ }^{58}$ This dexterous grasp was deemed elegant at least into the eighteenth century, as Gerard de Lairesse's successful manual for painters instructs. In order to determine the 'effects of education between people of condition and more common persons', one should note that a subject's character 'appears in their carriage, shape, graceful motion and pleasant colouring, as being people of education'. ${ }^{59} \mathrm{He}$ illustrates this principle with 'some different handlings of the same thing in persons of different conditions', holding a glass being his first example [4]. In Figure 4, no. 5, Lairesse depicts the typical hold of a goblet: 'below the foot', 'handily and cautiously', characterizing 'the manner of a prince'.

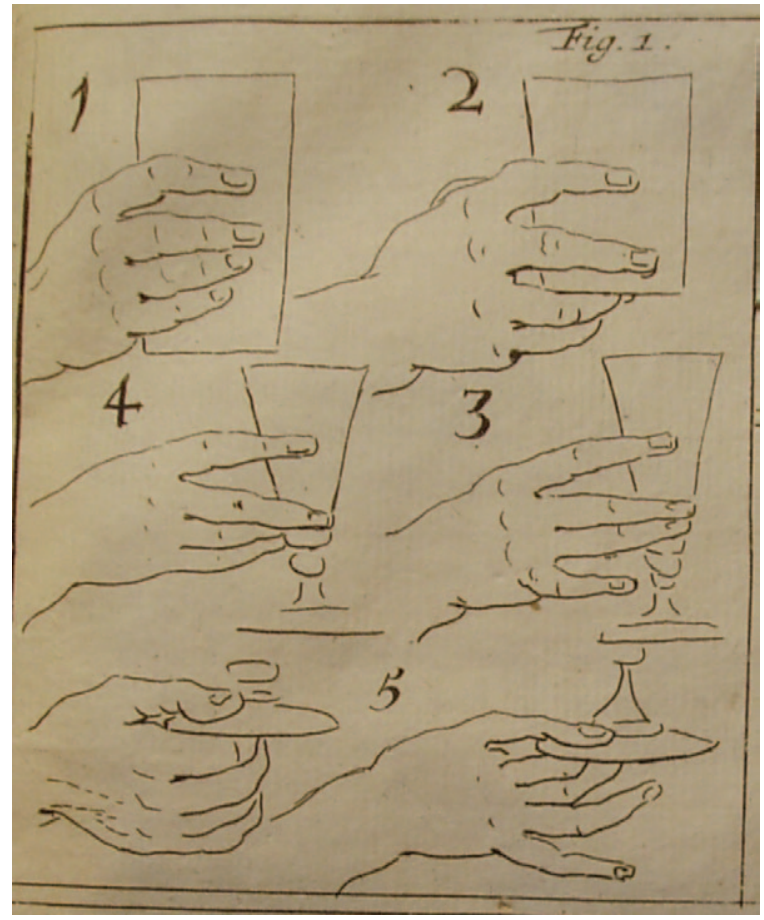




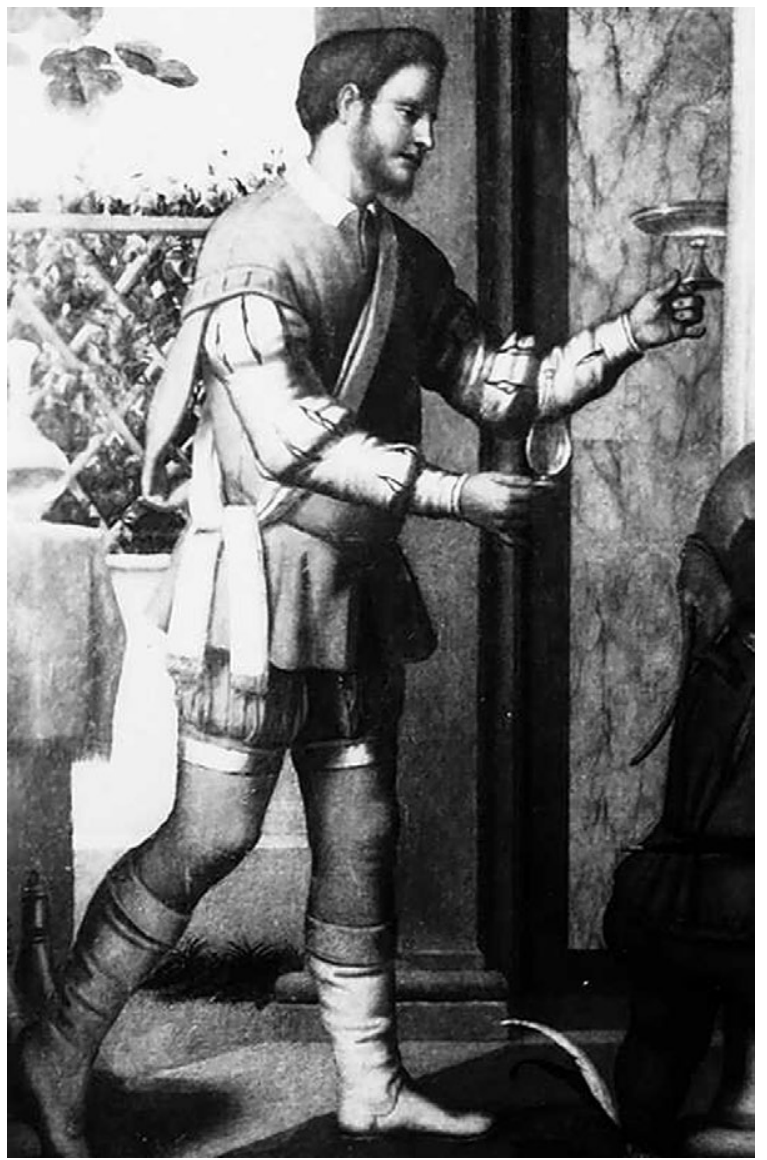

Fig 5. Alessandro Bonvicino, Moretto da Brescia (14981554), Christ in the House of Simon the Pharisee, 1544 church of Santa Maria della Pietà, Venice, Italy, detail: the cupbearer. Photo: Alinari/Art Resource, NY

\section{The meanings of Veronese's goblets}

Both versions of Wedding at Cana by Veronese (1563 and 1571) depict very special glasses with a wide, shallow bowl resting on a baluster stem [1, 5, 6, 7]. The history of the goblet (which remains to be written) indicates the novelty of those wine cups. The Italian term (calice) points to its origin in the chalice (itself derived from the footed Greek cup called kylix). 60 Thus, footed goblets with a knop and a flared or funnel-shaped bowl resemble pre-twelfth century chalices, while stemmed goblets with a knob and a deep cup are reminiscent of later chalices. The combination in glass of a tall stem and a cup appeared in rare instances in the twelfth century but became more common in the late thirteenth century, especially in France. In late Medieval and Renaissance times, stemmed goblets with a variety of shapes for the cup were overall reserved for special occasions and belonged to the upper classes (see next section). ${ }^{61}$

The model depicted by Veronese was probably first created in glass on the Murano island in the 1530s.62 It was a veritable breakthrough from earlier vessels - the dominant shape in Medieval and Renaissance Europe being the beaker, whether of glass, wood, stoneware, or fired glazed clay. Even fifteenth-century luxury glasses from Venice, such as enamelled nuptial cups, tended to look like an elegant beaker elevated on a stem - when they did not adopt the shape of a broad bowl on a flared foot. ${ }^{63}$ Historians of decorative arts call 'tazza' a vessel with a large and shallow bowl on a (usually) low foot, originally meant as a dish (averaging twenty-five centimetres in diameter) presenting sweetmeats or fruit, such as Veronese's silver 'tazze' placed on the tables of Cana [1]. ${ }^{64}$ However, from the late sixteenth century, 'tazze' also designate wine cups made in precious metal or glass. Their broad (circa fifteen centimetres in diameter) and shallow-rimmed bowls are set on a high stem. ${ }^{65}$

A distinctive feature of Veronese's wine cups is precisely the shape of their stem, an inverted baluster. ${ }^{66}$ Once the tazza-on-a-baluster design was invented for glasses, it was immediately adopted by silversmiths, reversing a trend for the first time. ${ }^{67}$ Goblets with a stem that is either hollow (blown) or full (whether plain or decorated), became the typical Renaissance glasses of the elite but they were not specifically designed for weddings, as iconography proves. ${ }^{68}$ The appearance of this bulbous form on glass vessels may reflect contemporary debates on the antiquity of this architectural element. An invention of the late Quattrocento, balustrades appear notably in the designs of Michelangelo, Serlio and Palladio for real or fictitious buildings. ${ }^{69}$ The long parapet behind Christ in Cana [1-2] points to the predominant type used by Palladio in the 1560s, with simple balusters, devoid of complex mouldings. In the wine glasses, the baluster is comparable but inverted instead of 'dropped'. This visual link between contemporary architecture and glass design stresses Veronese's modernity in depicting this sumptuous wedding.

Regarding a drinker's bodily command, the width of a baluster allows for a better grip than a full, thin, 'leg'. But being hollow, such a stem lightens up the weight of the glass and demands a steady hand. Veronese's cupbearer [2] rests his goblet on his fifth 


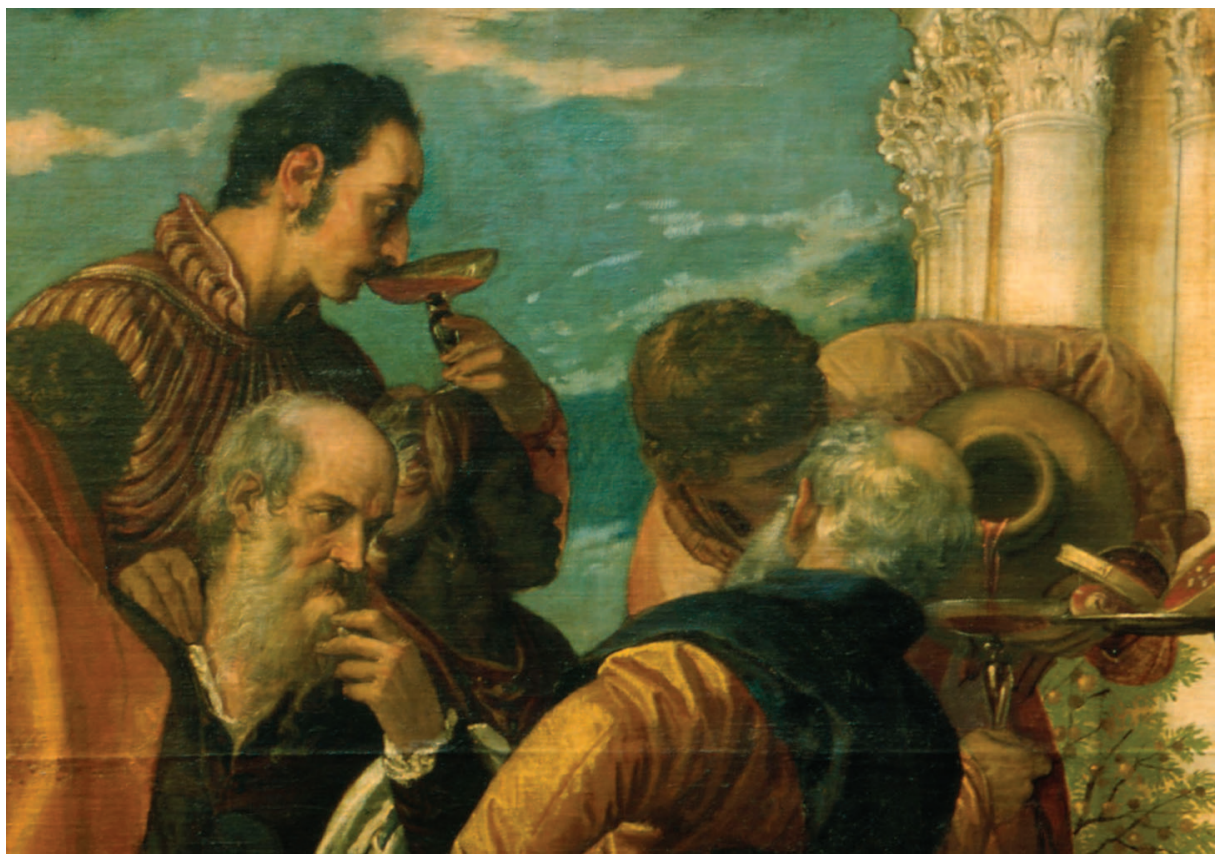

finger while his other fingers firmly press the top of the foot letting the baluster and bowl blossom from his hand. Veronese's Christ at Supper in the House of Simon [7], a guest just off centre shows a related grasp, with his index finger supporting the bowl. Caravaggio's Bacchus (1598) offers another elegant way of demonstrating his effortless bodily control, by holding the base of the baluster with thumb, index and middle fingers, delicately raising his pinkie. This most graceful hand attitude 'drawing warily and agreeably the little finger from [the cup]' 'is [typical of] a princess, according to Lairesse [4, no. 3]. However, not detaching your fifth finger [4, no. 4] reveals a character who is typically 'a lady's woman [lady-in-waiting] who, fearful of spilling, holds the glass handily, yet less agreeably than the other [i.e. the princess]'. ${ }^{70}$

Funnel-, chalice-, or tazza-shaped goblets required skilful balancing in one's hand, but they also demanded further self-control during the absorption of the beverage. 'What is more comforting than to show the sparkling stars the ass of a glass [after a salty salad]?' says Teofilo Folengo's pre-Rabelaisian hero Baldus. Erasmus would answer that it is rude to 'tip one's head back like a stork to catch the last drop from the bottom of the glass'. ${ }^{71}$ Annibale Carraci's Boy drinking [3], although correctly holding his vessel between thumb and index finger, illustrates this impolite action. The opposite head gesture, a pronounced forward tilt, characterizes the boorish manners of the German halberdiers in Veronese's Feast in the House of Levi (1573, Accademia, Venice) or the low condition of the unshod boy in the right foreground of Veronese's Christ at Supper in the House of Simon [7]. ${ }^{72}$

Veronese's goblets posed a further challenge to the drinkers because of their shallow and wide bowl. You could not possibly tilt the cup without spilling, thus, you had to dip your lips into the liquid with a gentle bow of the head while maintaining an erect posture [6]. As Paul Hills noted, 'the long-stemmed wineglasses have a poise and balance that is like an extension of the body'. ${ }^{73}$ Richard Lassels, a tutor of the English nobility, remarks in his Voyage or a Complete Journey through Italy (1670): 'Italians [. . . ] have glasses that are almost as large and flat as sylver plats, and almost
Fig 6. Paolo Veronese, The Wedding at Cana (detail), c. 1571, Gemaeldegalerie Alte Meister, Staatliche Kunstsammlung, Dresden, Germany. Photo: bpk, Berlin/ Gemaeldegalerie Alte Meister/ Hans-Peter Klut/Art Resource, NY 


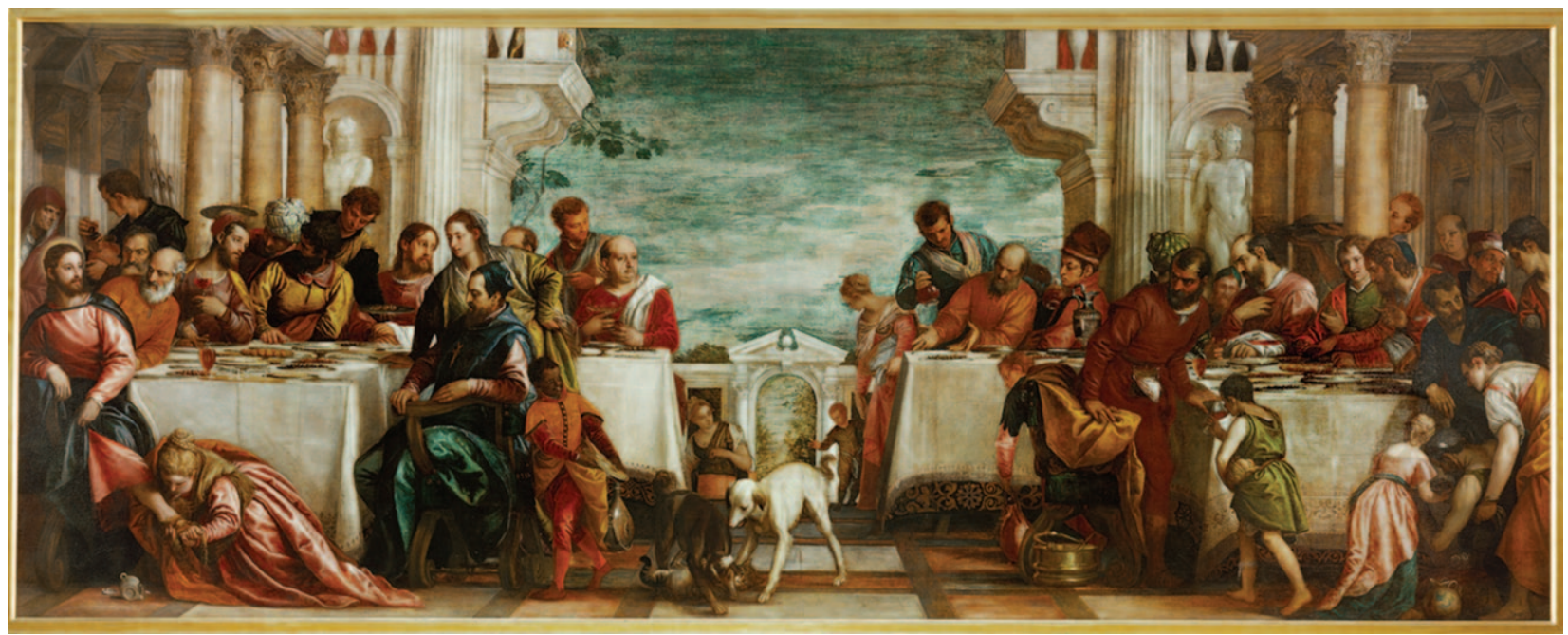

Ficg 7. Paolo Veronese, Christ at Supper in the House of Simon, c. $1570,275 \times 710 \mathrm{~cm}$, Pinacoteca di Brera, Milan, Italy. Photo: Erich Lessing/Art Resource, NY

Figg. 8. Alessandro Allori (1535-1607), Banquet of Syphax of Numidia, Receiving Scipio after His Defeat of Hannibal in Spain, 1578-1582, Villa Medici, Poggio a Caiano (Prato), Italy, detail. Photo: Scala/ as uneasy to drink out of'. ${ }^{74}$ With other types of goblets, a distinguished person would drink with his head slightly back, mimicking the gentle tilt of the glass, as the reclining guest on the far right in Alessandro Allori's Banquet of Syphax (1582) demonstrates [8].

Non-stemmed drinking vessels generate a much-differentiated body language. Common people throughout Europe used beakers, whether of glass, wood, stoneware, or fired glazed clay, which they held in their full palm or with both hands. Men and women could even drink directly from the pitcher, as does a female servant in the foreground of Dürer's woodcut of the Birth of the Virgin (1503) or a male guest in the background of Brueghel's Peasant Wedding (1568, Kunsthistorisches Museum, Vienna). Other stemless shapes of vessels, such as the hanaps, tankards, flagons and roemers used in Northern Europe, call for a grasp with the full hand and a backward tilt of the head in order to drink, in a position prone to gulping. As Montaigne observed, 'Germans' goal is to swallow wine rather than taste it', which is in line with Guazzo's fictitious guests stating that Art Resource, NY

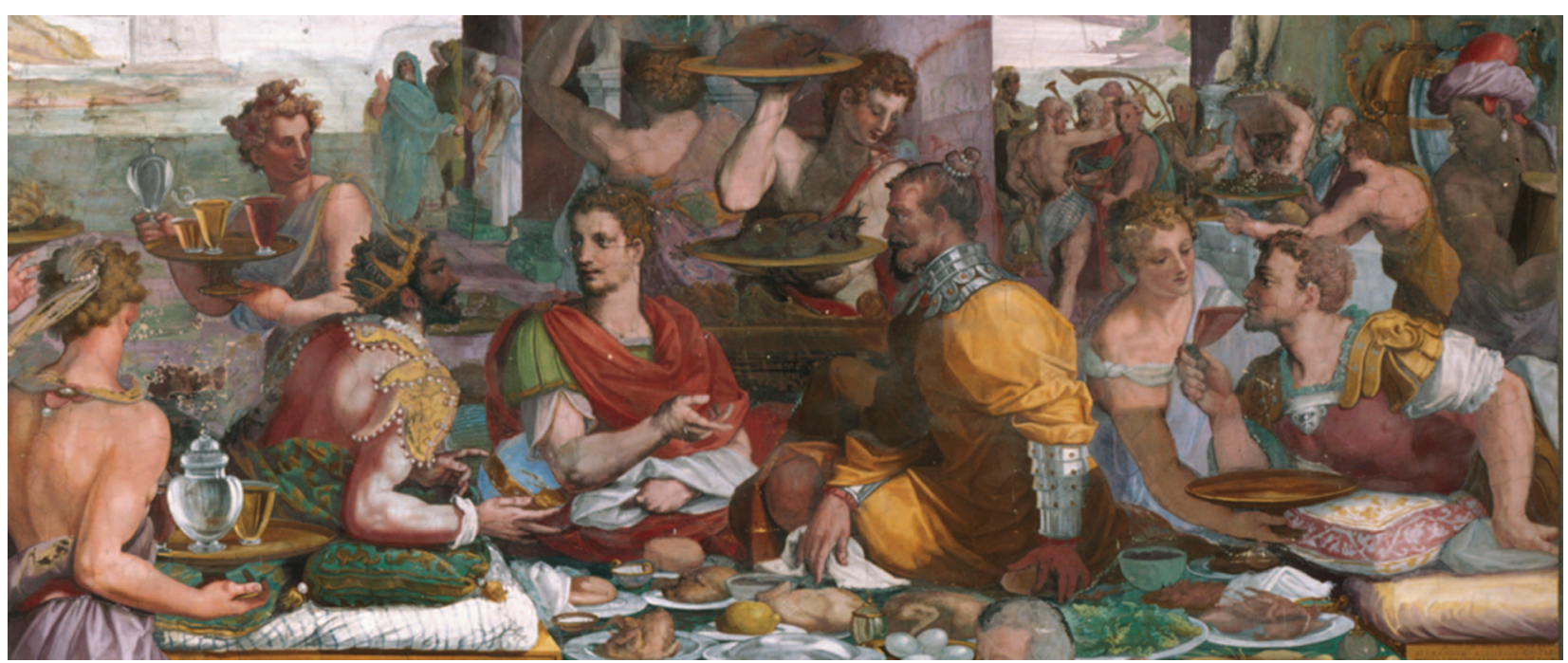

Pascale Rihouet 
Germans notoriously drink like brutes, mistreating the wine, and so 'they break their own necks'. ${ }^{75}$ This manner is clearly associated with gluttony ('gula') in Bosch's tabletop showing the Seven Deadly Sins (c. 1500, Prado Museum, Madrid).

Reinforcing the message of self-advancement promoted by etiquette books, a stemmed glass sustained the practice of self-fashioning, because it dictated a self-conscious and refined way of holding the vessel. ${ }^{76}$ In addition, stemmed glasses slowed down a drinker's gestures and thus urged moderation (or mediocritas), not only in the physical action of drinking but also in the quantity imbibed. 'Italians love to drink leisurely' observed Richard Lassels as he connects this national style with the shape of Italian glasses. By contrast, the drinking vessels favoured by sixteenth-century Northerners offered a straightforward grasp and, coupled with their larger sizes, encouraged a repetitive and excessive absorption of alcohol. ${ }^{77}$ The concept of mediocritas, recommended by the Ancients and revived in humanist and Christian thought, led to the virtue of 'temperance', or as Alvise Cornaro argued in his Tratatto della Vita Sobria (1558), to living a long and healthy life. ${ }^{78}$ Moderation in eating and drinking was an essential quality of princes and an attitude expected of virtuous diners in banquets. ${ }^{79}$ The slender and elegant goblets of Renaissance Italians (and their exports) responded to and reinforced their reputation of measurement and refinement but masked the reality of excessive consumption of alcohol that characterized tavern life. As implied earlier, the design of wine glasses also participated in the process of conversation and social interaction that alcohol favours, not to mention toasting rituals. ${ }^{80}$

\section{Goblets between commodity and luxury}

Glass design had multifarious implications for consumers; it influenced the drinker's behaviour and revealed his social class. ${ }^{81}$ It is probably safe to say that in Medieval and early Renaissance Europe, elevated cups (whatever their material) were reserved for the elite, but if we look at glass this image is far from homogeneous in Europe. ${ }^{82}$ In a princely wedding in Quattrocento Italy, stemmed vessels distinguished the highest-ranked diners, while in contemporary England, they were reserved for ceremonial use. ${ }^{83}$ However, it is difficult to delineate with precision the consumption of stemmed glasses in the 1400s and 1500s, notwithstanding the questions of dating that arise constantly for this period. ${ }^{84}$ The best preserved glasses come from private and museum collections with little information on provenance. In archaeology, the area of Medieval and Renaissance glass was neglected for a long time. Even in recent times, excavated material may not always be properly analysed for lack of funding. 85

From the fifteenth century, the technical achievements of Murano glass masters in moving towards higher qualities of transparency (cristallo) or gem-like appearance turned fine glass into a desirable acquisition for the upper social strata. ${ }^{86}$ The scholarship on Renaissance glass often focuses on technical innovations, on shapes and colours, dating and provenance, and on the supremacy of Venice in terms of craftsmanship, trade and luxury glass. ${ }^{87}$ However, one should not forget that the production of most glass workshops, including those of Murano, essentially consisted of everyday objects, and above all drinking vessels, often mould-blown for efficiency and naturally tinged. ${ }^{88}$

Archaeological records reveal that footed cups (also called pedestal goblets) and beakers that were each made out of a single parison (bubble) were the most common type of tableware from Italy to England in the fifteenth century. ${ }^{89}$ In Venetian excavations, the most common vessel for the period $1350-1450$ is the undecorated beaker. ${ }^{90}$ This corresponds with the bigger picture of glass consumption in late Medieval Italy: the 
Fig 9. Giuseppe Maria Mitelli, 'The Glutton' from the series Le Ventiquattr' hore dell' humana felicità, Plate 5, Bologna, 1675, $27.2 \times 19.3 \mathrm{~cm}$. Photo: Biblioteca Casanatense, Rome. Reproduced with permission from Biblioteca Casanatense

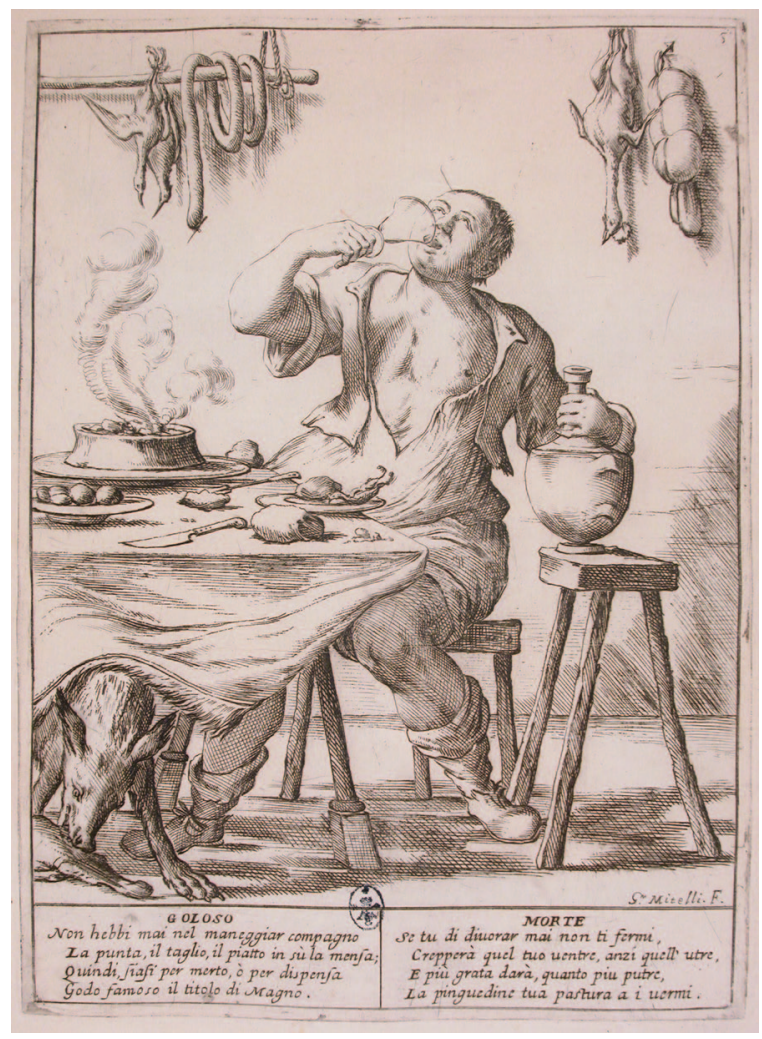

common table had one glass beaker per person, while only the wealthy used glassware of higher qualities, including beakers, goblets and bottles, or acquired fine luxury glass for display purposes. ${ }^{91}$

In the sixteenth century, the divulging of techniques through treatises or glassmasters' emigration, the use of local raw materials, serial production and the elimination of transportation costs contributed a more widespread use of glass domestic vessels, whether luxurious or ordinary. Common goblets were a local, cheap production made of potash glass (crystal-clear costly goblets were instead made of alkali, an imported flux). They looked slightly coloured with greenish reflections, due to batches not purged of their iron impurities. Even 'the poorest also will have glass if they may' remarked an observer of the English nobility in 1587.92 When Isabelle Palumbo-Fossati asserts that, in late sixteenth-century Venice, glass was rare in popular and mercantile households, she must mean artistic or luxury glass such as baluster goblets. 93

In Italy, the most widespread type of glass in Italy from the second half of the sixteenth century became the goblet in its many variants and prices. ${ }^{94}$ By the end of the sixteenth-century, goblets were used by the lower classes in Italy, as archeological finds and iconography confirm. ${ }^{95}$ For example, Carracci's rustic Bean Eater (1584-1585, Galleria Colonna, Rome) avails himself of a simple funnel-shaped goblet while his Vendor of glassware (known through seventeenth-century prints) sells elegant baluster-stemmed goblets on the streets. ${ }^{96}$ Because of the popularity of goblets at the end of the sixteenth century, I do not see the presence of this glass in Carracci's Bean Eater as an anomaly. That such glasses became common domestic objects in the seventeenth century is evidenced in prints such as Giuseppe Mitelli's Glutton [9] and his Poor Man Eating his Meal by His Hearth. ${ }^{97}$ Once the lower classes could acquire footed or stemmed glasses, they mimicked and assimilated the refined gestures of the upper strata such as holding a glass with a few fingers only. Artists provide visual evidence for this acculturation. For example, Carracci's Boy of 1582 [3] and Mitelli's Glutton [9] hold a goblet by its foot between thumb and index finger. ${ }^{98}$ These observations point to a needed revision of Elias' timeframe for the permeation of courtly models to the middle classes. According to him, this phenomenon occurred gradually during the second half of the seventeenth century but further research on drinking manners could lead to antedate this model by several decades.

Veronese's goblets belonged to the type of luxury glassware which the courtly-aristocratic circles adopted for formal table gatherings. ${ }^{99}$ For example, the tazza held by Caravaggio's Bacchus was part of the collection of Cardinal del Monte in Rome. ${ }^{100}$ Their unadorned surfaces make them look deceptively plain, whereas their fabrication was a complex process requiring an experienced glass master and one assistant to assemble a succession of three bubbles in a laborious fifteen-minute expert task. This contrasts sharply with a simple stemmed cup, which would take five minutes, or a beaker, which took two minutes, or less if mould-blown. Another, practical reason for this social restriction in their diffusion is the challenge that they 
posed to the drinker, proving them unsuited for frequent use. Lastly, they were made of the most expensive type of glass, the almost defect-free cristallo, which at the end of the fifteenth century cost a hundred times more than ordinary glass. ${ }^{101}$

The most transparent glass, cristallo, was a significant technological feat of the mid-Quattrocento, and it quickly spread from Venice to other glass centres in Italy and Europe. ${ }^{102}$ Although more labour-intensive, cristallo was conducive to more elaborate shapes thanks to the lower viscosity and higher fluidity of the batch. Free of foreign material, bubbles or striations (which gave a wavy appearance to the glass), Venetian cristallo glasses, with their wafer-thin walls, were superior to other precious materials because, to quote an English traveller, they were 'delicate' and incomparably 'fine'. ${ }^{103}$ However, from 1535, the hallmarks of such deluxe glass (absolute clarity, lightness and thinness) were not limited to the output of Murano glasshouses, thanks to the migration of skilled Italian workers. ${ }^{104}$ These 'façon de Venise' (i.e. manufactured in the Venetian style) vessels were produced elsewhere in Italy (for example, in Altare, near Genoa) and in major cities (such as Antwerp, London, or Brussels), or else in locations of princely patronage (Florence; Hall in Tyrol). ${ }^{105}$ Beyond aesthetic implications, transparency also allowed spotting the possible presence of poison in banquets, hence the advice of the authoritative medicinal treatise Regimen Sanitatis Salernitatum to use drinking vessels made of glass. 106 In addition, Venetian glasses were thought to shatter instantly when in contact with a drop of poison, or, as a French royal physician wrote in 1540, 'some people believe that glass cannot stand venom or poison [. . . ]. The natural electron detects poisons that shimmer in goblets like rainbows, ripple like flames, and split'. ${ }^{107}$ This superstition is probably linked to the visual similarity between rock crystal (considered apotropaic) and cristallo.
Figy 10. Jacopo Ligozzi, Design for a triple-bowl tazza in glass, 1617, Gabinetto Disegni e Stampe degli Uffizzi, Florence, no. 97166. Photo: Gabinetto fotografico, Soprintendenza Speciale per il Patrimonio Storico. Reproduced with permission from Soprintendenza Speciale per il Patrimonio Storico

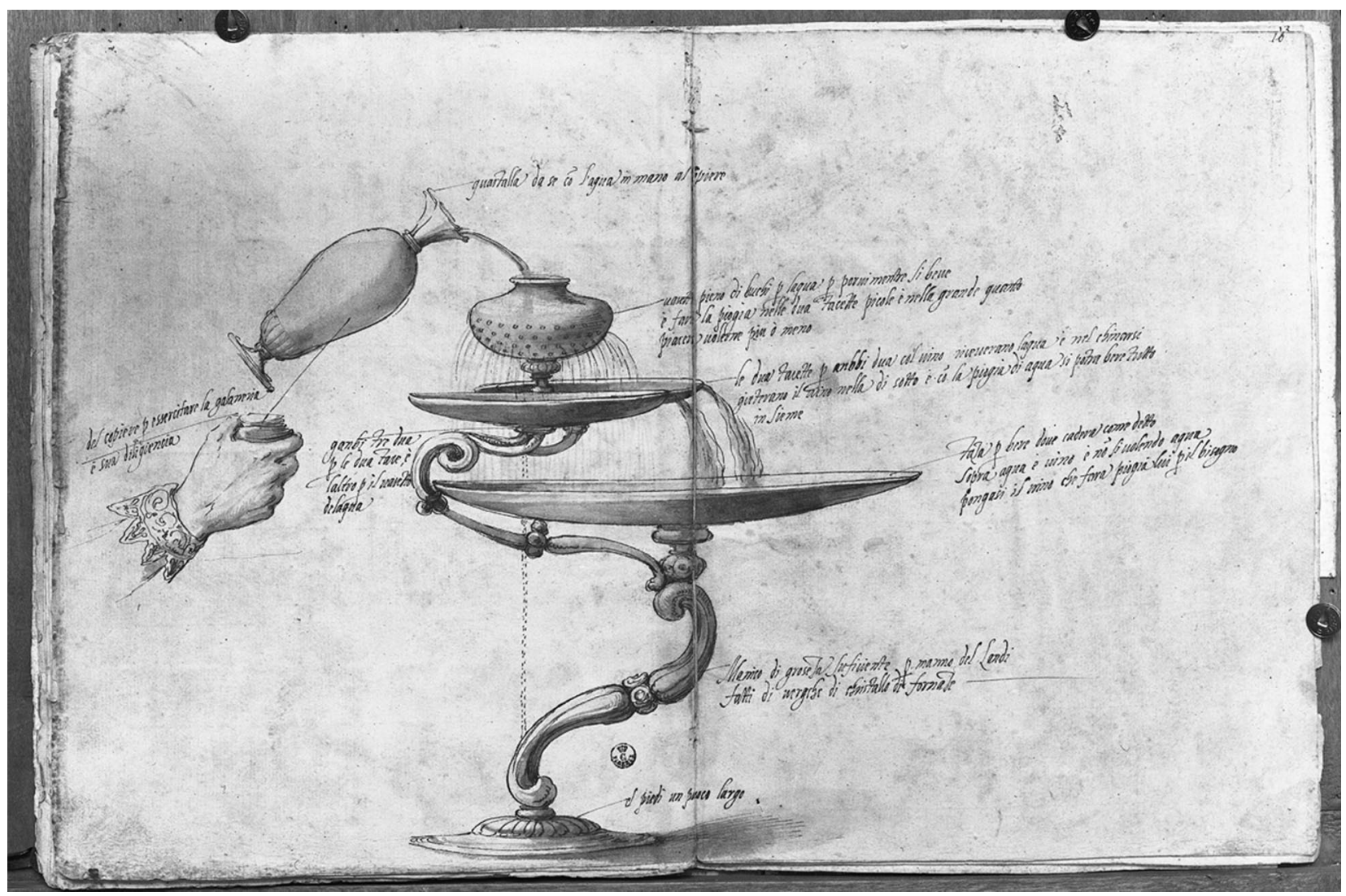




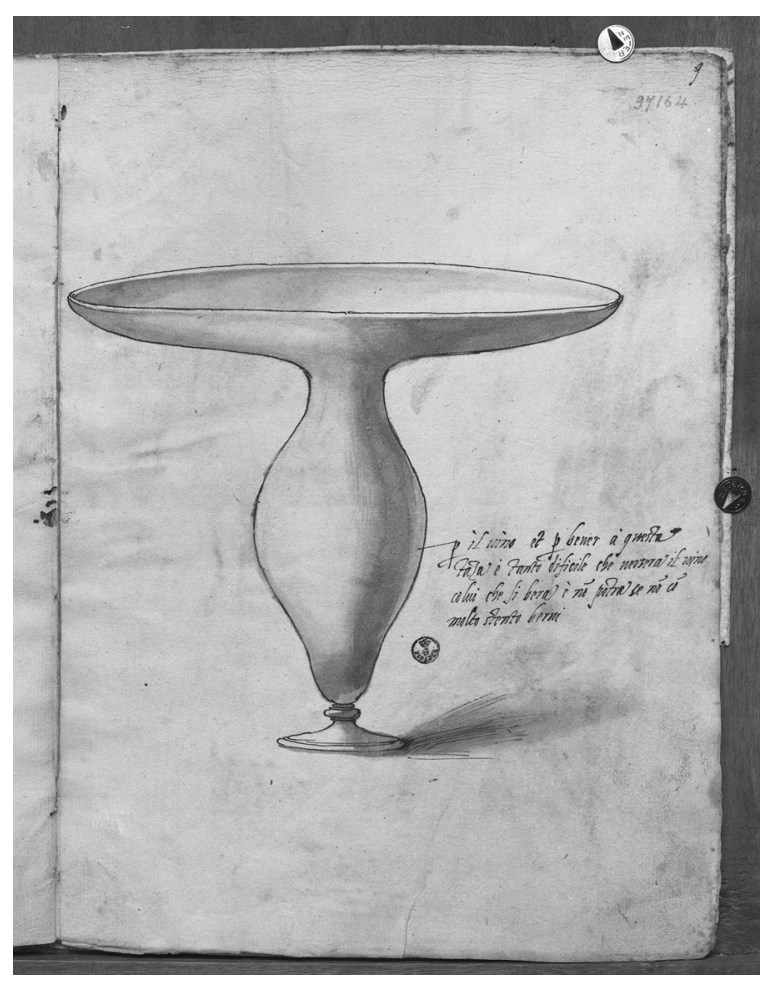

While the origin of the baluster-stemmed tazza is difficult to circumscribe more accurately, this article has implied that sophisticated shapes responded to a demand ('a social need', Elias would say) for demonstrating one's civilized manners in public. The self-control demanded of the drinker using elegant goblets probably stimulated the emergence of a related category, that of even more complicated vessels, called 'trick glasses'. ${ }^{108}$ Giovanni Maggi's Bicchierografia (1604) presents 1,600 designs for elaborate glass vessels, including balusterstemmed ones. ${ }^{109}$ In 1617, Jacopo Ligozzi, who had studied with Veronese, produced for the Grand Duke of Tuscany twenty-nine extraordinary drawings of glasses. These early modern drawings prove that artists and glass masters envisioned the challenges posed to drinkers. Complex shapes for drinking glasses were sought and destined to flabbergast and entertain the elite. ${ }^{110}$ Ligozzi's captions help understand the motivation behind his eccentric shapes such as his triple-bowl glass [10] that looks like an outgrowth of the Renaissance tazza. The guest is supposed to drink from the large bowl without spilling the wine and water being mixed in the upper smaller bowls. The far left inscription, 'to exercise the diligence and gallantry of the cupbearer' (del coppiere per esercitare la galanteria e sua diligencia), illustrates the performative feat expected of this noble officer and the

Fig 11. Jacopo Ligozzi, Design for a glass tazza, 1617, Gabinetto Disegni e Stampe degli Uffizzi, Florence, no. 97164 . Photo: Gabinetto fotografico, Soprintendenza Speciale per il Patrimonio Storico. Reproduced with permission from Soprintendenza Speciale per il Patrimonio Storico spectacle produced by ultra-sophisticated glassware. Another drawing [11] recalls Veronese's goblets, except for the narrow diameter of the disc-shaped base and for the exaggerated inflation of the baluster. Its caption specifies that 'to drink from this tazza is so hard that the person drinking from of it [. . .] will not be able to, if not with great difficulty'. ${ }^{111}$ Outside of Italy, other trick glasses, impossible to use properly unless one decoded their structure, took the form of wager cups or dice glasses. ${ }^{112}$ They were mostly destined for the entertainment of courtiers of Germany and the Netherlands, as far as extant examples testify. Like beer 'passglasses' (decorated with rings marking the amount of one gulp), they were passed around during professional or convivial gatherings in the late Renaissance and Baroque eras. ${ }^{113}$ This was a logical development of the expert handling of glasses in society, pushing the challenge to its limits.

Veronese's 'passing faire picture of an exceeding breadth and length' [1] still offers a mental journey into a courtly feasting world. ${ }^{114}$ The exquisite baluster-stemmed glasses on which I focused were first acquired by the elite for ostentation in banquets, and not only on account of their aesthetic and technological values. Perhaps more importantly, they urged controlled gestures and body posture, allowing the display of grace and sprezzatura. Glass design held an important role in the performance of the good manners expected of diners or servants, because body language around drinking vessels denoted the degree and level of your education, and revealed your social status. By the end of the sixteenth century, when simple goblets became commodities, common people found in them a table tool with which they could, if they chose to, emulate the civil conduct of upper classes.

This essay has only surveyed a small area of the idea of glasses as performative indicators of one's manners and personality. Beyond the scope of this article are gendered ways of drinking, relations between the sexes in banquets, or toasting rituals. A brief 
incursion into the refectory of San Giorgio Maggiore where Veronese's Wedding at Cana hung, reveals another connotation for glasses. By opposition to the graceful manners and superb glasses depicted by Veronese, the Venetian Benedictines preferred drinking from simple ceramic bowls. Thus, they managed to distance themselves from the secular life of pleasure and sophistication of the upper secular classes. ${ }^{115}$ In their frugal and meditative life, the exclusion of even simple glass beakers highlighted the sensual delight of taste, touch, or smell that glassware could, then as now, offer.

Pascale Rihouet

Rhode Island School of Design, Providence, RI, USA

E-mail: prihouet@risd.edu

Art historian Pascale Rihouet (PhD 2008, EHESS, Paris/Brown University) has been since Spring 2008 part-time faculty at the Rhode Island School of Design, where she teaches a variety of courses including, in 2009-2010, 'History of Glass'. She has published two articles based on her dissertation 'The Unifying Power of Moving Pictures in Renaissance Umbria'. Her first book, The Material Culture of Processions in Renaissance Italy, is currently under review by Ashgate.

If you have any comments to make in relation to this article, please go to the journal website on http://jdh.oxfordjournals.org and access this article. There is a facility on the site for sending e-mail responses to the editorial board and other readers.

Acknowledgements: I wish to thank the Gladys Krieble Delmas Foundation and the Rhode Island School of Design for funding various research trips linked to this article. I am also especially grateful to Evelyn Lincoln and Mary Bergstein for their support and inspiration, and to the anonymous reviewers who helped improve this essay.

\section{Notes}

1 B. Castiglione, /l libro del cortegiano, G. Carnazzi (ed.), Rizzoli, Milan, 1998, p. 81. See also Harry Berger, The Absence of Grace. Sprezzatura and Suspicion in Two Renaissance Courtesy Books, Stanford University Press, Stanford, CA, 2000, pp. 9-25.

2 Originally published in 1939 in Basel, Elias' book first appeared in two distinct volumes: The History of Manners, Blackwell, Oxford, 1969, and State Formation and Civilization, Blackwell, Oxford, 1982, E. Jephcott (trans.). I have used the revised edition and translation in one volume: N. Elias, The Civilizing Process, E. Dunning et al. (eds.), Blackwell, Oxford, 2000.

3 A. Appadurai, 'Introduction: Commodities and the Politics of Value', in The Social Life of Things, A. Appadurai (ed.), Cambridge University Press, Cambridge, pp. 3-63.

4 The quote is the original title of Elias' first part (volume one) to which this article contributes.

5 Inspiring authors include P. Burke, The Italian Renaissance: Culture and Society in Italy, Princeton University Press, Princeton, NJ, 1987, R. C. Trexler, Public Life in Renaissance Florence, Academic Press, Waltham, MA, 1980, E. Muir,
Ritual in Early Modern Europe, Cambridge University Press, Cambridge, 1997, M. Casini, I gesti del principe: La festa politica a Firenze e Venezia in eta rinascimentale, Marsilio, Venice, 1996; anthropologist Clifford Geertz and 'thick description'; art historians Mimi Hellman and Dena Goodman on the sociability of eighteenth-century furniture, and Jerome Bachet (and his concept of the 'image-object').

6 J. Habert (ed.), Les Noces de Cana de Veronese. Une oeuvre et sa restauration, Réunion des Musées Nationaux, Paris, 1992.

7 Veronese also followed Pietro Aretino's own account of the Biblical event. P. Fehl, Decorum and Wit: the poetry of Venetian Painting, Irsa, Vienna, 1992, pp. 261-81. See also I. Smirnova, 'Le cene Veronesiane. Problemi iconografici', in Nuovi Studi su Paolo Veronese, M. Gemin (ed.), Arsenale, Venice, 1990, pp. 359-64.

8 For further discussion, see L. Urban, Banchetti veneziani dal Rinascimento al 1797, Strategy \& People, Rome, 2007, and R. Strong, Feast. A History of Grand Eating, Harcourt, Orlando, 2002, pp. 129-209. 
9 G. Rossetti, Dello scalco [. . .] e gli ordini di una casa da principe, F. Mammarello, Ferrara, 1584, quoted in C. Benporat, Cucina e convivialita italiana del Cinquecento, Olschki, Florence, 2007, pp. 14-15. Rossetti was scalco and maestro di casa at the Este court from 1557 to 1576. See also Strong, op. cit., pp. 134-7.

10 'Officio del schalco del signore', in Ordini et offitii de casa de lo illustrissimo Signor Duca de Urbino, S. Eiche (ed.), Accademia Raffaello, Urbino, 1999, pp. 90-1. This manuscript (c. 1480s) created a model for the management of a court. See also A. Manciuli, 'Le arti della tavola', in Et coquatur ponendo. Cultura della cucina e della tavola in Europa tra medioevo e età moderna (exh. cat.), G. Nigro \& A. J. Grieco (eds.), Istituto internazionale di storia economica Francesco Datini, Prato, 1996, pp. 325-45.

11 According to my interpretation, Marie Viallon-Schoneveld misidentified the steward as the cupbearer and vice versa: 'Véronèse: noces et banquets', Le boire et le manger au XVle siècle, in M. Viallon-Schoneveld (ed.), Université de St-Etienne, St-Etienne, 2004, pp. 258-9.

12 See C. Benporat, 'La singolare dottrina di Domenico Romoli detto Panonto', Appunti di gastronomia, no. 12, October 1993, pp. 5-13. Romoli's book was first published in 1560 and followed by six editions up to 1610 . The cupbearer is also described as 'young, noble, clean, and of good appearance' in the Urbino manuscript edited by S. Eiche, op. cit., p. 92.

13 The cupbearer also supervises the cellar and the 'bottigliere' officer. S. Sigismondi, Prattica cortigiana morale, et economica, Baldini, Ferrara, 1604, p. 55.

14 lbid., p. 57.

15 See the essays of W. R. Rearick, O. Bordaz and M. Favier, in Habert, op. cit. On sugar sculptures, see Strong, op. cit., pp. 194-202, and C. Benporat, 'La "collation", una nuova forma conviviale', Appunti di gastronomia, no. 52, February 2007, pp. 45-58, and Benporat, Cucina, op. cit., pp. 97-8.

16 See C. Young, 'The Sexual Politics of Cutlery', in Feeding Desire: Design and The Tools of the Table, 1500-2005, S. Coffin et al. (eds), Cooper-Hewitt National Design Museum, New York, 2006, pp. 104-12.

17 R. Tyson, Medieval Glass Vessels Found in England ca. 1200-1500, Council for British Archaeology, York, 2000, pp. 29-31.

18 For example, in Book 4 of Stefano Guazzo's didactic novel La Civil conversatione, 1574, guests pass a ship-shaped vessel around to mark the change of speakers during their witty and most 'civil' interaction; A. Quondam (ed.), Panini, Modena, 1993 (reprinted 2010).

19 For further discussion, see Nigro \& Grieco, op. cit., and D. Romagnoli (ed.), La ville et la cour: des bonnes manières, Fayard, Paris, 1995, pp. 25-87.
20 Elias, Civilizing Process, op. cit., p. 53. Elias mentions only three clerical authors. For a thorough review, see A. Grieco \& A. Manciuli, 'La codificazione del modo di stare a tavola', in Nigro \& Grieco, op. cit., pp. 108-14.

21 Hugh's definition of 'gestus' implies that an external gaze is what coerces one to display adequate manners. D. Poiret et al. (eds), L'oeuvre de Hugues de Saint-Victor. 1. De institutione novitiorum, Brepols, Turnhout, 1997, ch. 12, 'On the discipline that one must keep in one's gestures', and ch. 21, 'On the manner of eating', pp. 59-75, 99. See also J. C. Schmitt, La raison des gestes dans I'occident médieval, Gallimard, Paris, 1990, pp. 173-205.

22 On Medieval secular texts in Latin or vernacular, see Schmitt, op. cit., pp. 224-9, and S. Glixelli, 'Les contenances de table', Romania, vol. 47, 1921, pp. 1-40).

23 Bonvesin de la Riva, 'De quinquaginta curialibus ad mensam', in Poeti del Duecento, G. Contini (ed.), Ricciardi, Milan, 1960, vol. 1, pp. 703-12.

24 G. Croce, Cinquanta cortesie, overo creanze [good manners] da tavola, Bonfadino, Venice, 1608 (reprint of 1609 available at <www.giuliocesarecroce.it/testi/cinquanta_cortesie.html> accessed 22 November 2012).

25 S. Bertelli \& G. Calvi, 'Rituale, cerimoniale, etichetta nelle corti italiane', in Rituale, cerimoniale, etichetta, S. Bertelli \& G. Crifò (eds), Bompiani, Milan, 1985, p. 12. See also J. Snyder, 'Norbert Elias' The Civilizing Process today and the critique of conduct', in Educare il corpo, educare la parola nella trattistica del Rinascimento, G. Patrizi \& A. Quondam (eds), Bulzoni, Rome, 1998, pp. 23-41.

26 Between 1558 and 1598, it appeared thirty-nine times by itself or in polyglot editions. See A. Santosuosso, The Bibliography of Giovanni Della Casa. Books, Readers, and Critics 1537-1975, Olschki, Florence, 1979.

27 Elias, Civilizing Process, op. cit., p. 66. For similar adaptations with Platina's scholarly gastronomy best-seller of 1475, see T. Tomasik, 'Translating Taste in the Vernacular Editions of Platina's De Honesta voluptate et valetudine', in At the table. Metaphorical and Material Cultures of Food in Medieval and Early Modern Europe, T. Tomasik \& J. Vitullo (eds), Brepols, Turnhout, 2007, pp. 189-210.

28 Elias, Civilizing Process, op. cit., pp. 65-6. See also Strong, op. cit., pp. 160-1.

29 Elias, Civilizing Process, op. cit., p. 60. 'Civility' comes from the French 'civilité', the condition of being civil, urbane and courteous, as Robert Estienne defined it in 1549. See J.-C. Margollin, 'La civilité nouvelle: de la notion de civilité à sa pratique et aux traités de civilité', in Pour une histoire des traités du savoir-vivre en Europe, A. Montandon (ed.), Faculté des Lettres et Sciences Humaines, Clermont-Ferrand, 1994, pp. 151-77.

30 Elias, Civilizing Process, op. cit., p. 181. 
31 J. Duindam, Myths of Power: Norbert Elias and the Early Modern European Court, Amsterdam University Press, Amsterdam, 1994, pp. 102-7.

32 Elias, Civilizing Process, op. cit., p. 71.

33 E. Acanfora, 'La tavola', in Bertelli \& Crifò, op. cit., pp. 53-66.

34 The same prescription is in an English poem of c. 1480: See The Babees' Book. Medieval Manners for the Young Now first done into Modern English from the Texts of Dr. F. J. Furnivall, Cooper Square, New York, 1966, p. 19.

35 For further examples, see Strong, op. cit., pp. 127, 203.

36 A. Latini, Lo scalco alla moderna (published in Naples in 1594), quoted in R. Morelli, 'Protocollo e cerimoniale presso le corti romane del 600', Appunti di gastronomia, no. 19, February 1996, pp. 18-26, at p. 20. See also M. Dykmans, L'oeuvre de Patrizi Piccolomini ou le cérémonial papal de la première Renaissance, Biblioteca Apostolica Vaticana, Città del Vaticano, 1980, and Benporat, Cucina, op. cit., pp. 84-5.

37 C. Bellosio, 'Cerimoniale e precedenze sulla cena conviviale italiana', Appunti di gastronomia, no. 56, June 2008, p. 66, quoting the Duke's secretary's diary published in 1629. For cardinals, see Morelli, op. cit., p. 23. When a lord drank, the scalco and all other servants had to uncover their heads, a practice reported in A. Frugoli, Practica e scalcheria da servire a quasivoglia mensa di principe, Rome, 1631. See also Bertelli \& Crifò, op. cit., pp. 19-20.

38 'Del scoprirsi la testa al bere del Prencipe', in Delle lettere miscellanee del signore Bonifatio Vannozzi Dottor Pistolese, \& Protonotario Apostolico, Giacomo Paolo Gelli, Rome, 1608, pp. 28-9.

39 In Venice, bottles were left on the table; consequently, to avoid stains, a saucer was placed under them. See T. Folengo, Baldus, 1517, E. Faccioli (ed.), Einaudi, Turin, 1989, libro II, pp. 136-7, verses 251-5.

40 For example, 'Stans Puer ad Mensam' of c. 1430, in The Babees Book, op. cit., p. 28.

41 As described by Romoli, op. cit., chs 5, 14.

42 F. Priscianese, Del governo della corte di un signore in Roma, 1543, quoted in Benporat, Cucina, op. cit., p. 19. The Urbino manuscript specifies that 'the cupbearers must be [. . . ] capable of serving with greatly reverent and dexterous gestures and do the assay \{against poison\} of wine and water with due ceremony'; ibid., p. 18.

43 On the cupbearer's precise gestures, see ibid., pp. 56-7, quoting Romoli and Evitascandalo.

44 Vannozzi, op. cit., p. 29.

45 F. Collard, 'Le banquet fatal: la table et le poison dans I'occident médiéval', in La sociabilité à table: commensalité et convivialité à travers les âges, M. Aurell et al. (eds), Université de Rouen, Rouen, 1992, pp. 335-42.

46 Benporat, Cucina, op. cit., p. 31. See also G. Panciroli, Raccolta breve d'alcune cose piu segnalate ch'hebbero gli antichi, Giunti, Venice, 1612, p. 240.

47 Also articulated in c. 1475 as: 'If your lord is pleased to offer you his own cup to drink, rise when you take it, and receive it goodly with both your hands [. . .]', The Babees' Book, op. cit., p. 5; and in Croce's thirty-fifth and forty-second rules: 'Do not address your neighbour when he is drinking; this could cause him to spill easily'/'Do not fill up a glass too much when you serve [wine]'.

48 Croce's twelfth rule exceptionally permits the use of both hands in case a 'dissipated' person ('un dissoluto') overfilled your cup.

49 This rule appears in an early fifteenth-century poem, reelaborated by Sulpitius Verulanus and published in 1473. See M. Martini (ed.), Il carme giovanile di Giovanni Sulpizio Verolano. De moribus Puerorum in mensa servandis, Centro di Studi sorani 'Vicenzo Patriarca', Sora, 1980, pp. 52-3. This prescription also applies to eating in Europe and was already formulated by Muslim scholar Al-Ghazali (d. 1111) for the Islamic world. See H. Spode, Alkohol und Zivilisation, TaraVerlag Hartmut Hensel, Berlin, 1991, p. 54.

50 My evidence comes from the Directives of c. 1501 for Florentine Dominican tertiaries and commentaries to the fortieth chapter of the rule of St Benedict (De mensura potus) that the Cassinense Congregation printed from 1520 into the 1600 s. See note 115

51 A drinking bowl is shallow and has no foot or handle. A beaker ('gobelet' in French) is a common drinking glass with or without a base; it has a cylindrical, barrel, or trunconical shape. Goblets encompass two types of vessels, footed and stemmed glasses.

52 The Vasari paintings were made respectively for the Olivetan monastery San Michele in Bosco (now in the Pinacoteca nazionale, Bologna) and for the Benedictine Monastery of Saints Flora and Lucilla, Arezzo (now in the Museo statale $d^{\prime}$ arte medioevale e moderna, Arezzo).

53 The word 'beaker' lost currency when Deming Jarves invented a machine to make pressed glass 'tumblers'. T. Bredehoft, Glass Tumblers 1860 to 1920s. Identification and Value Guide, Collector Books, Paducah, KY, 2004, p. 5.

54 Examples in P. Thornton, The Italian Renaissance Interior, 1400-1600, Abrams, New York, 1991, fig. 233, and D. Foy, A travers le verre du moyen âge à la renaissance, Musées et Monuments départementaux de la Seine-Maritime, Rouen, 1989, fig. 192

55 Examples include: Book of Hours, end of fifteenth century (ms. 3116, Bibliothèque nationale de France [BnF], Paris), f.1v reproduced in Gastronomie mediévale <http:// 
expositions.bnf.fr/gastro/enimages/salle3/index.htm> accessed 21 November 2012; Book of Hours, Use of Tours, c. 1500 (ms. Lat. 886, BnF, Paris); follower of Fouquet, Man with a glass of wine, c. 1460 (Louvre Museum).

56 In French, gobelet means beaker or tumbler. Goblets ('verres') are divided into 'à tige' (stemmed) ones, i.e. without mereses, and 'à jambe' (legged) ones, i.e. with merese(s) and/or a knop.

57 Other examples include the Hours of Marguerite d'Orléans (ms. lat. 1156b, BnF, Paris, f. 1) reproduced on Gastronomie <http://expositions.bnf.fr/gastro/grands/123.htm> accessed 22 November 2012; Maarten van Heemskerck, Pieter Jan Foppesz and his Family, c. 1530 (Staatliche Museen, Kassel). For Venetian glasses of this shape made in 1583, see I. Lazar \& H. Willmott, 'The Glass from the Gnalic wreck-Preliminary Report', in Annales du 17 ème Congrès. Association Internationale pour l'histoire du verre (AIHV), Aspeditions, Antwerp, 2006, p. 334.

58 For examples, see The De Moucheron Family (Rijksmuseum, Amsterdam) and Antoon Claeissens's Banquet (1574, Groeninge Museum, Bruges).

59 G. de Lairesse, Groote Schilderboek, 1707, The Art of Painting in all its Branches (trans.), London, 1738, pp. 38-9. Plate 54 also depicts: 'holding a spoon' and 'standing while listening to someone'.

60 Simple shallow bowls in glass appears in the Persian Empire in the fifth and fourth centuries BCE and are common in Roman antiquity. H. Tait (ed.), Five Thousand Years of Glass, British Museum, London, 2005, p. 47. Earthenware Greek kylikes elevate such a bowl on a flared and squat foot. See also P. Springer, 'Chalice'. Grove Art Online. Oxford Art Online <http://0-www.oxfordartonline.com.librarycat. risd.edu/subscriber/article/grove/art/T015734> accessed 15 November 2011, and Foy, op. cit., pp. 357-9.

61 This is not true of fourteenth-century France. See note 82.

62 A. Gasparetto, in Mille anni di arte del vetro a Venezia, R. Mentasti Barovier et al. (eds), Albrizzi, Venice, 1982, p. 25, with no rationale for this dating. The first paintings that show this design are Veronese's Wedding at Cana of 1563, and Frans Floris, Family van Berchem of c. 1561 (Museum Wuyts Campen en Baron Caroly, Lier, Belgium).

63 For various types of 'marriage glassware', see A. Bayer (ed.), Art and Love in Renaissance Italy, Metropolitan Museum of Art, New York, 2008, pp. 93-9.

64 'Tazza' applies rather to silver in Renaissance Italy. M. Cortellazzo, Dizionario veneziano della lingua e della cultura popolare nel XVI secolo, La Linea, Padua, 2007, entry 'tazza'. It could also designate a footless drinking bowl or a wide dish with fresh water to cool glasses, see C. Benporat, 'Convivialità, cucina e decori delle tavole nella Firenze del Quattrocento', Appunti di gastronomia, no. 28,
February 1999, p. 11. A 'tazza da puerpera' was a ceramic vessel for hot restorative liquids given to a new mother. See S. Valsasina, 'Desco da parto, tazza della puerpera, ongaresca: da utensil a oggetti d'arte', Appunti di gastronomia, no. 52, February 2007, pp. 77-8.

65 For drawings of wine tazze, see J. F. Hayward, 'Ottavio Strada and the Goldsmiths' Designs of Giulio Romano', The Burlington Magazine, vol. 112, no. 802, January 1970, pp. 10-14, and V. Taylor, 'Art and the Table in sixteenth-century Mantua: Feeding the Demand for Innovative Design', in The Material Renaissance, M. O'Malley \& E. Welch (eds), Manchester, 2007, pp. 174-96. In the 1610s, Jacopo Ligozzi designates several of his glass designs as 'tazze'. See D. Heikamp, 'Studien zur mediceischen Glaskunst: Archivalien, Entwurfszeichnungen, Gläser und Scherben', Mitteilungen des Kunsthistorischen Institutes Florenz, no. 30, 1986, pp. 197-221.

66 Many seventeenth-century English glasses (in particular Ravenscroft's 'baluster style') derive from this shape; A. Gasparetto, 'Le relazioni fra venezia e I'Inghilterra bei secoli XVI e XVII e la loro influenza sulle forme vetrarie inglesi', Vetro e silicate, vol. 14, July-August 1970, pp. 16-20.

67 A. Gruber, Silverware, Rizzoli, New York, 1982, p. 70. Glassmakers always sought to imitate goldsmiths. See also T. Schroder, Renaissance Silver from the Schroder Collection, The Wallace Collection, London, 2007, pp. 106-7; 112-13.

68 Examples include El Greco, Last Supper, 1567-1570 (Pinacoteca Nazionale, Bologna); Jacopo Bassano, Christ in the House of Marta, 1577 (Blaffer Foundation, Houston); Leandro Bassano, Last Supper, 1578 (Louvre, Paris); and J. Beltrame (attr.), Last Supper, 1618 (Cathedral of San Pietro, Venice).

69 See P. Davies \& D. Hemsoll, 'Renaissance balusters and the antique', Architectural History, vol. 26, 1983, pp. 1-30, which corrects and complements R. Wittkower, 'The Renaissance Baluster and Palladio', in Palladio and Palladianism, R. Tavernor (ed.), Braziller, New York, 1974, pp. 41-8.

70 Lairesse, op. cit., p. 39.

71 Folengo, op. cit., pp. 138-9. Erasmus's quote is in chapter 4, 'De conviviis', of De Civilitate morum puerilium.

72 'Nor in the cup deeply sink' warns the English poem 'Urbanitatis' of 1446-1460. Babees' Book, op. cit., p. 14.

73 Paul Hills briefly proposed what I develop in this article: fine glass was more a statement about manners (inducing poise in drinkers) than about wealth. See 'Venetian Glass and Renaissance Self-fashioning' in Concepts of Beauty in Renaissance Art, F. Ames-Lewis and M. Rogers (eds), Ashgate, Aldershot, 1998, pp. 163-78.

74 Quoted in Heikamp, op. cit., p. 14. 
75 Montaigne is quoted in Margollin, op. cit., p. 159; Guazzo, op. cit., vol. 1, libro IV, p. 278. For further debate, M. Montanari, La fame e abbondanza, Laterza, Rome, 1993, pp. 137-45, and L. Martin, Alcohol, Sex and Gender in Late Medieval and Early Modern Europe, Palgrave, New York, 2001.

76 Strong, op. cit., p. 161, discussing the 'acute awareness that manners actually mattered' in the Renaissance.

77 The 'vice of the Germans is to use glasses beyond measure' (i.e. excessively large). Montaigne, Journal de voyage, 1580, F. Garavani (ed.), Gallimard, Paris, 1983, pp. 179-80.

78 Romagnoli, op. cit., pp. 48-50; A. Brucioli, Dialogi, 1526, A. Landi (ed.), Prismi, Naples, 1982, pp. 325-8. A. Cornaro, Tratatto della vita sobria, 1558, M. Stern (ed.), II Polofilo, Milan, 2004.

79 See G. Pontano, De Principe, 1493, G. Cappelli (ed.), Salerno editrice, Rome, 2003, p. 77.

80 For toasting rituals, see A. Tlusty, Bacchus and Civic Order: the Culture of Drink in Early Modern Germany, University Press of Virginia, Charlottesville, 2001, and Heikamp, op. cit., ch. 1.

81 Glass design has also an impact on taste. See <www.riedl. com> accessed 28 November 2010.

82 See the frescoed 'dinner of Abbot Guido' (abbey of Pomposa, c. 1316); for a tavern context, Liefkes, op. cit., p. 38, fig. 39. In France, stemmed goblets, common in the fourteenth century, became rare in the fifteenth century until the fashion for 'legged' glasses reappeared under the influence of Italy. See Foy, op. cit., pp. 199-221, 281-5; J. Barrera, 'Le verre à boire des fouilles de la Cour Napoléon du Louvre', Annales AIHV, 11 ème Congrès, Oxbow Books, Oxford, 1988, pp. 347-64; and H. Cabart, La verrerie archéologique Dieulouard et l'Est de la France aux XVI et XVIIe siècles, Presses universitaires de Nancy, 2011.

83 C. Benporat, Feste e banchetti: convivialità italiana fra tre e quattrocento, Olschki, Florence, 2001, p. 201. By contrast, in fifteenth-century England, glasses were used by prosperous classes. See Tyson, op. cit., p. 27.

84 Foy, op. cit., 255. For issues concerning provenance, place of manufacture, reconstruction and date of glass vessels, see E. Baumgartner, 'On Researching the Glass from the Karl Amendt Collection', in Glass des späten Mittelalters und der Renaissance. Die Sammlung Karl Arendt, E. Baumgartner \& H. Ricke (eds), Düsseldorf, Museum Kunst Palast, Glasmuseum Hentrich, 2005, pp. 53-63.

85 This was the case for the digs in the Louvre courtyards of the 1980s. Oral communication of glass curator Jean-Luc Olivié, Musée des Arts Décoratifs, Paris, August 2011.

86 The drop of silver prices in the sixteenth century, due to large imports from the Americas, must have reinforced this phenomenon.
87 See H. Tait, The Golden Age of Venetian Glass, British Museum, London, 1979; Barovier Mentasti et al., op. cit.; E. Baumgartner \& J. L. Olivié, Venise et façon de Venise. Verres renaissance du Musée des Arts Décoratifs, Union centrale des arts décoratifs, Paris, 2003; P. McCray, Glassmaking in Renaissance Venice: The Fragile Craft, Ashgate, Aldershot, 1999; L. Syson \& D. Thornton, 'Glass and Maiolica: Art and Technology', in Objects of Virtue: Art in the Renaissance, The Getty Museum, Los Angeles, 2001, pp. 182-200. Corinne Maitte critiques McCray's categorization of artistic glass and its association with luxury: Les chemins de verre: les migrations des verriers d'Altare et de Venise, XVIe-XIXe siècles, Presses universitaires de Rennes, Rennes, 2009, pp. 71-4.

88 On the consumption of ordinary glass by Italian middle classes and for further evidence of its widespread production, see Maitte, op. cit., pp. 74-8. 80\% of the total sales of Murano glass concerned vessels of all types, whether luxury or ordinary: McCray, op. cit., p. 136

89 McCray, op. cit., pp. 81-2; Foy, op. cit., 255-7; S. Ciappi, II vetro in Toscana. strutture, prodotti, immagini: secc. XIIIXX, Lalli, Poggibonsi, 1995, pp. 88-9.

90 C. Pause, 'Spätmittlealterliche Glasfunde aus Venedig', Universitätsforschungen zur prähistorischen Archäologie, no. 28, 1996, pp. 65-7.

91 D. Stiaffini, 'The diffusion of mensa vitreous vessel in Italy during the Middle Ages. The archeological evidence', in Annales AIHV, 12ème Congrès, Oxbow Books, Oxford, 1995, pp. 343-52.

92 W. Harrison, The Description of England, G. Edelen (ed.), Cornell University Press, Ithaca, 1968, pp. 127-8.

93 I. Palumbo-Fossati, 'L'interno della casa dell'artigiano e dell'artista nella Venezia del Cinquecento', Studi veneziani, vol. 8, 1984, pp. 109-53, at pp. 123-4.

94 In Genoa and Tuscany, goblets became commodities from the end of the sixteenth century. D. Andrews, 'Vetri, metallic e reperti minori dell'aerea sud del convento di S. Silvestro a Genoa', in Archeologia medioevale, vol. 4, 1977, pp. 16289 , at p. 176.

95 D. Stiaffini, 'I reperti della lavorazione del vetro', in L'arte vetraria a Pisa. Dallo scavo di una vetreria rinascimentale, Fabio Redi (ed.), Pacini, Ospedaletto, 1994, pp. 69-87. A sixteenth-century drawing of a glass shop in Pistoia with goblets on its outdoor counters shows their availability. See Ciappi, op. cit., fig. 127, p. 86.

96 Annibale Carracci's Vendor of Glassware belonged to a series of (lost) drawings entitled the Cries of Bologna, etched by Simon Guillain and published in 1646. Mitelli's version may be based on Guillain's prints or on Carracci's original drawings. See A. Bertarelli, Le incisioni di G. Mitelli. Catalogo critico, Comune, Milan, 1940. 
97 Reproduced in Bertarelli, op. cit., and in John Spike (ed.), The Illustrated Bartsch: Italian Masters of the Seventeenth Century, vol. 42, Abaris Books, New York, 1981, p. 446.

98 Mitelli may be poking fun at his depraved rustic fellow for his elegant gesture; however, his drinking mode characterizes his sin, as in Bosch's tabletop.

99 See Giovanni Maggi's drawings of glass tazze in his fourvolume Bicchierografia, 1604, P. Barocchi (ed.), Studio per Edizioni scelte, Florence, 1977, vol. 2, pp. 78, 90, 101, 105. Original pieces can be found in major collections such as the Corning Museum of Glass and the Museo vetrario at Murano.

100 R. Mentasti Barovier, Trasparenze e riflessi. I/ vetro italiano nella pittura, Verona, Banco Popolare, 2006, p. 114, suggests this based on the drawings made by Giovanni Maggi in 1604 of the cardinal's glass collection. See also previous note.

101 McCray, op. cit., p. 77. For the three types of clear glass (common/vitrum blanchum/cristallo) and the technical achievements required for cristallo, see ibid., pp. 115-221, and G. Turner, "'Allume Catina" and the Aesthetics of Venetian "Cristallo"', Journal of Design History, vol. 12. no. 2, 1999, pp. 111-22.

102 Maitte, op. cit., pp. 30-5, deconstructs the 'myth' of Angelo Barovier as the inventor of cristallo. This technology was mastered in other glass centres by the end of the fifteenth century.

103 Thomas Coryat, Coryat's Crudities, London, 1611, vol. 1, p. 387.

104 Heikamp, op. cit., p. 88.

105 J.-A. Page (ed.), Beyond Venice: Glass in the Venetian Style, 1500-1750, Corning Museum of Glass, Corning, NY, 2004.

106 Opera utilissima di Arnoldo da Villanuova di conservare la sanità, Tramezzino, Venice, 1549, ch. 59, f. 108, quoted in C. Benporat, 'Veleni e contravveleni', Appunti di gastronomia, no. 35, June 2001, pp. 70-1: 'It is a good thing that suspecting poison [. . .] and right away, if you want to use wine, use rather white wine than another colour, and the cup should be in glass because in such glasses, the poison shows up right away'.

107 J.-B. Bruyérin-Champier, L'alimentation de tous les peoples et de tous les temps jusqu'au XVIe siècle, S. Amundsen (trans.), Intermédiaire des chercheurs et des curieux, Paris, 1998, p. 151. On superstitions, see A. Gaba-Van Dongen, 'Longing for Luxury. Some Social Routes of Venetian-Style Glassware in the Netherlands during the $17^{\text {th }} \mathrm{C}$. ', in Page, op. cit., pp. 192-3.

108 Heikamp, op. cit., describes throughout his book trick glasses made for the Medici court in Renaissance and Baroque Tuscany.

109 Ibid., pp. 186-8. Several designs are compared with extant exemplars in Ciappi, op. cit.

110 For all'antica designs, see Syson \& Thornton, op. cit., pp. 196-200. There is no extant visual record of Giovanni da Udine's designs; ibid, p. 199. For Giulio Romano, see Heikamp, op. cit., p. 20. Off topic here are 'bicchieri di capriccio' and 'trionfi da tavola' meant for display only. See Heikamp, op. cit., p. 20, and Ciappi, op. cit., pp. 80-1.

111 Heikamp, op. cit., figs 111, 197-212. See also L. Zecchin, 'Disegni vetrari del Seicento', in Vetro e vetrai di Murano: Studi sulla storia del vetro, vol. 1, Arsenale, Venice, 1986, pp. 122-8.

112 Y. Hackenbroch, 'Wager Cups', The Metropolitan Museum of Art Bulletin, New Series, vol. 26, no. 9, May 1968, pp. 380-8.

113 In a sermon delivered in 1562, criticizing the German habit of drinking bouts, pastor Johannes Mathesius, railed against the 'fools' glasses that one can hardly lift'. Quoted in Heikamp, op. cit., p. 26.

114 Coryat, op. cit., p. 245.

115 I deal with monastic drinking mores in a forthcoming article on the Venetian Refectory of San Giorgio Maggiore. 